\title{
Heparan sulfate and syndecan-1 are essential in maintaining murine and human intestinal epithelial barrier function
}

\author{
Lars Bode, ${ }^{1}$ Camilla Salvestrini, ${ }^{2}$ Pyong Woo Park, ${ }^{3}$ Jin-Ping Li, ${ }^{4}$ Jeffrey D. Esko, ${ }^{5}$ \\ Yu Yamaguchi, ${ }^{1}$ Simon Murch, ${ }^{6}$ and Hudson H. Freeze ${ }^{1}$
}

\begin{abstract}
${ }^{1}$ Burnham Institute for Medical Research, La Jolla, California, USA. ${ }^{2}$ Centre for Pediatric Gastroenterology, Royal Free Hospital, London, United Kingdom. ${ }^{3}$ Department of Medicine, Baylor College of Medicine, Houston, Texas, USA. ${ }^{2}$ Department of Medical Biochemistry and Microbiology, Biomedical Center, Uppsala University, Uppsala, Sweden. ${ }^{5}$ Department of Cellular and Molecular Medicine, UCSD, La Jolla, California, USA.

${ }^{6}$ Clinical Sciences Research Institute, Warwick Medical School, Coventry, United Kingdom.
\end{abstract}

\begin{abstract}
Patients with protein-losing enteropathy (PLE) fail to maintain intestinal epithelial barrier function and develop an excessive and potentially fatal efflux of plasma proteins. PLE occurs in ostensibly unrelated diseases, but emerging commonalities in clinical observations recently led us to identify key players in PLE pathogenesis. These include elevated IFN- $\gamma$, TNF- $\alpha$, venous hypertension, and the specific loss of heparan sulfate proteoglycans from the basolateral surface of intestinal epithelial cells during PLE episodes. Here we show that heparan sulfate and syndecan-1, the predominant intestinal epithelial heparan sulfate proteoglycan, are essential in maintaining intestinal epithelial barrier function. Heparan sulfate- or syndecan-1-deficient mice and mice with intestinal-specific loss of heparan sulfate had increased basal protein leakage and were far more susceptible to protein loss induced by combinations of IFN- $\gamma$, TNF- $\alpha$, and increased venous pressure. Similarly, knockdown of syndecan-1 in human epithelial cells resulted in increased basal and cytokine-induced protein leakage. Clinical application of heparin has been known to alleviate PLE in some patients but its unknown mechanism and severe side effects due to its anticoagulant activity limit its usefulness. We demonstrate here that non-anticoagulant 2,3-de- $O$-sulfated heparin could prevent intestinal protein leakage in syndecan-deficient mice, suggesting that this may be a safe and effective therapy for PLE patients.
\end{abstract}

\section{Introduction}

Failure to maintain intestinal epithelial barrier integrity can be fatal. Influx of bacteria and bacterial products cause necrotizing enterocolitis (1) and sepsis (2); excessive efflux of plasma proteins into the intestinal lumen causes protein-losing enteropathy (PLE). PLE develops as a symptom in ostensibly unrelated disorders, including Crohn disease (3), multiple congenital disorders of glycosylation (CDG) (4-6), and systemic lupus erythematosus (7) or as a long-term complication of Fontan surgery to correct congenital heart malformations (8).

Emerging commonalities from clinical observations of PLE patients alerted us to key features of PLE pathogenesis (9-11). It is episodic, and the onset is often associated with viral infections and increased IFN- $\gamma$ levels $(12,13)$ as well as with a proinflammatory state and increased TNF- $\alpha$ levels (14). IFN- $\gamma$ and TNF- $\alpha$ disrupt tight junctions (15-17) and induce paracellular protein leakage (9-11). PLE can result from mesenteric venous hypertension. Fontan surgery, for example, leads to general venous hypertension (18). CDG-Ib patients, whose $N$-glycosylation is impaired due to genetic phosphomannose isomerase deficiency, develop hepatic fibrosis and portal hypertension $(4,5,19)$. Increased pres-

Nonstandard abbreviations used: AAT, $\alpha 1$-antitrypsin; CDG, congenital disorders of glycosylation; dp, degree of polymerization; 2/3-DS-H, 2,3-de-O-sulfated heparin; GAG, glycosaminoglycan; HS, heparan sulfate; HSase, heparinase III; HSPG, HS proteoglycan; HS(PG), HS and HSPG; IEC, intestinal epithelial cells; PLE, protein-losing enteropathy; rh-, recombinant human; rm-, recombinant mouse; Sdc1, syndecan-1; TER, transepithelial electrical resistance.

Conflict of interest: The authors have declared that no conflict of interest exists. Citation for this article: J. Clin. Invest. 118:229-238 (2008). doi:10.1172/JCI32335. sure directly causes protein leakage across epithelial monolayers in vitro, which is further amplified upon IFN- $\gamma / \mathrm{TNF}-\alpha$ exposure (11). These results correlate with clinical observations in postFontan patients: venous pressure increases shortly after surgery, causing a subtle increase in intestinal protein leakage (20). However, PLE manifests only months to years after the surgery when additional insults, usually viral infections, strike (12). Half of the post-Fontan patients with PLE die (8), due in large part to inadequate therapeutic options, which are currently limited to albumin infusions and medications that improve hemodynamics or mitigate inflammation, but these treatments are often accompanied by serious side effects (21).

The most intriguing commonality in PLE patients is the specific loss of heparan sulfate (HS) from the basolateral surface of intestinal epithelial cells (IEC) during PLE episodes $(6,22,23)$. Not only HS, but also syndecan-1 (Sdc1), the predominant HS proteoglycan (HSPG) on IEC, disappear (6). HS and Sdc1 reappear when PLE resolves, suggesting a functional link between HS and HSPG [HS(PG)] loss and protein leakage. HS(PG) loss in glomeruli has been implicated in the development of proteinuria (24). Whether $\mathrm{HS}(\mathrm{PG})$ loss also contributes to protein leakage in the intestine is unknown. To address this question, we established an in vitro PLE model and showed that paracellular albumin flux through monolayers of human HT29 IEC indeed increases in the absence of cell-associated HS $(9,11)$.

High-molecular-weight heparin reverses PLE in some post-Fontan patients (25-27), but the basis and mechanisms are unknown. IFN- $\gamma$ and TNF- $\alpha$ bind to both HS and heparin $(28,29)$, which may lower the local concentration of active cytokines that would 

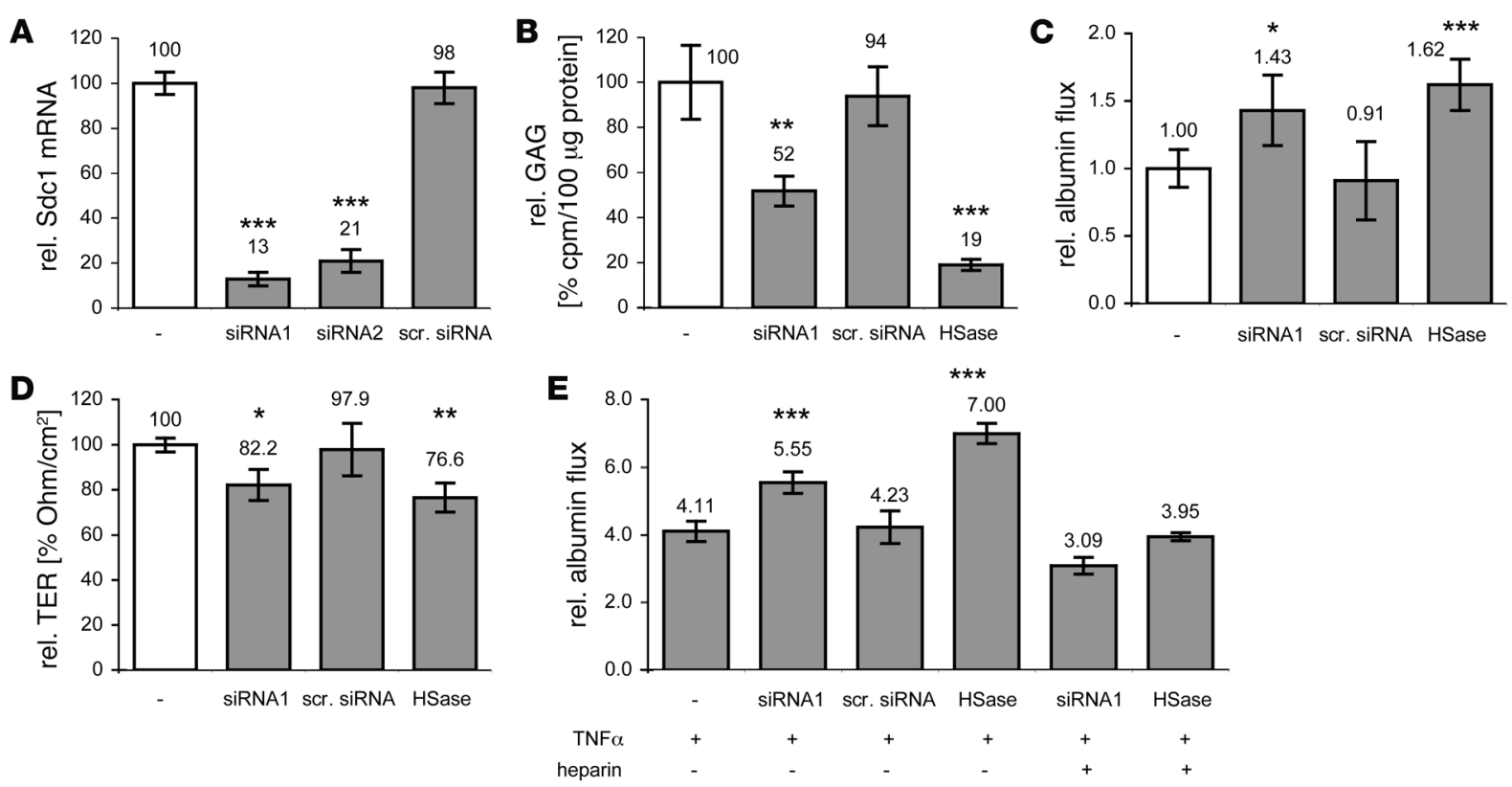

\section{Figure 1}

Sdc1 knockdown in HT29 cells causes protein leakage. (A-E) Sdc1-targeting siRNAs (siRNA1 and siRNA2) reduce Sdc1 mRNA level (A), reduce cell-associated GAGs $(\mathbf{B})$, increase relative albumin leakage $(\mathbf{C})$, reduce TER (D), and amplify TNF- $\alpha$-induced protein leakage $(\mathbf{E})$, which can be reversed with heparin. Compared with effects of HS loss after exposure to HSase or scrambled siRNA (scr. siRNA) as negative control. White bars represent basal levels without intervention. ${ }^{\star} P<0.05,{ }^{* \star} P<0.01,{ }^{\star * \star} P<0.001$.

otherwise impair intestinal epithelial integrity. In fact, we have shown that soluble heparin compensates for loss of cell-associated HS and prevents IFN- $\gamma /$ TNF- $\alpha$-induced protein leakage in vitro $(9,11)$. Since long-term therapy with anticoagulant heparin has severe side effects, including bleeding, thrombocytopenia, and osteoporosis $(27,30)$, an alternative therapy is needed.

Prior studies of PLE pathomechanisms and therapeutic options were limited to in vitro cell culture models or experiments on dogs carrying an unknown genetic defect $(31,32)$. Here we present what we believe to be the first model to study intestinal protein leakage in mice, which allows us to control and mimic both genetic insufficiencies and environmental insults in an in vivo setting. We adapted well-established clinical assays $(33,34)$ to assess intestinal protein leakage in mice. We found that loss of HS or Sdc1 directly caused protein leakage and made the intestine more susceptible to proinflammatory cytokines and increased pressure. Heparin and non-anticoagulant 2,3-de- $O$-sulfated heparin (2/3-DS-H) prevented cytokine-induced protein leakage both in vitro and in mice.

\section{Results}

Sdc1 knockdown causes protein leakage in vitro. First we assessed whether Sdc1 loss causes protein leakage in vitro. Sdc1 siRNA knockdown in HT29 cells reduced Sdc1 mRNA levels by $87 \% \pm 3 \%$ (Figure 1A) and decreased the amount of cell-associated glycosaminoglycans (GAGs) by $48 \% \pm 7 \%$ (Figure 1B). In parallel, paracellular protein leakage increased $1.43 \pm 0.26$-fold and transepithelial electrical resistance (TER) decreased by $17.8 \% \pm 6.9 \%$ (Figure 1, B-D). Neither cell growth nor apoptosis were affected (data not shown). Incubating HT29 cells with HS-cleaving heparinase III (HSase) reduced cell-associated GAGs by $81 \% \pm 3 \%$, increased protein leakage $1.62 \pm 0.19$-fold, and decreased TER by $23.4 \% \pm 6.5 \%$. The latter results are in accordance with our previous studies
$(9,11)$ and also indicate that loss of HS increases protein leakage more than just the loss of the predominant HSPG, Sdc1.

$S d c 1$ knockdown amplifies $T N F-\alpha-i n d u c e d$ protein leakage in vitro. In the presence of HSPGs, TNF- $\alpha(20 \mathrm{ng} / \mathrm{ml})$ increased protein leakage $4.11 \pm 0.30$-fold (Figure $1 \mathrm{E})$. In the absence of cell-associated HS after exposure to HSase, TNF- $\alpha$ increased protein leakage $7.00 \pm 0.29$-fold, showing that HS loss and TNF- $\alpha$ synergize. Incubating Sdc1 knockdown cells with TNF- $\alpha$ increased protein leakage $5.55 \pm 0.32$-fold over baseline, indicating that the effects of Sdc1 loss and TNF- $\alpha$ also synergize. Again, loss of HS was more effective than just the loss of the major HSPG Sdc1. Coincubating TNF- $\alpha$ with soluble heparin $(25.0 \mu \mathrm{g} / \mathrm{ml})$ alleviated TNF- $\alpha-$ induced protein leakage.

Intestinal protein leakage is increased in Sdc1-/- or intestinal HS-deficient mice. To study whether HS loss also causes intestinal protein leakage in vivo, we established 2 independent methods to assess enteric protein loss in mice, one determining fecal loss of ${ }^{51} \mathrm{Cr}$-labeled albumin, the other measuring fecal levels of $\alpha 1$-antitrypsin (AAT) (10). The 2 methods gave comparable results, varying less than $10 \%$. We applied them to mice deficient in Sdc1 or all HS. In $\mathrm{Sdc1}^{-/-}$mice HS expression on the basolateral surface of IEC was significantly reduced (Figure 2, A and B) and basal intestinal protein leakage was significantly increased compared to wild-type littermates (Figure 2C).

Since treatment of cultured mucosal cells with HSase increased protein leakage to a greater extent than deletion of Sdc1, we next addressed whether general loss of intestinal epithelial HS further exacerbates protein leakage. Ext1 encodes a subunit of the copolymerase involved in HS formation (35). Since systemic knockout of Ext1 is embryonic lethal (36), we inactivated the gene selectively in IEC $\left(E x t 1^{\Delta / \Delta}\right)$. HS expression on the basolateral surface of IEC was further reduced compared with $S d c 1^{-/-}$mice (Figure 2, 
A
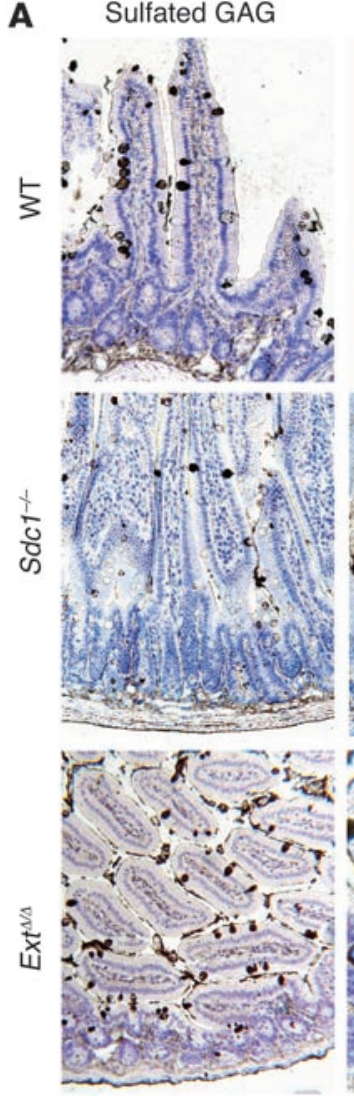

B

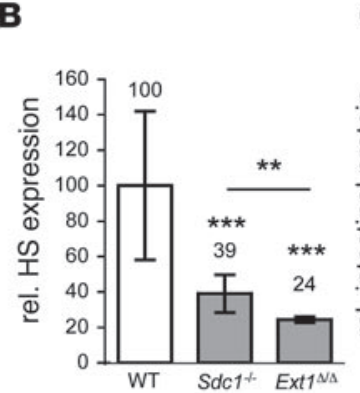

Sulfated GAG
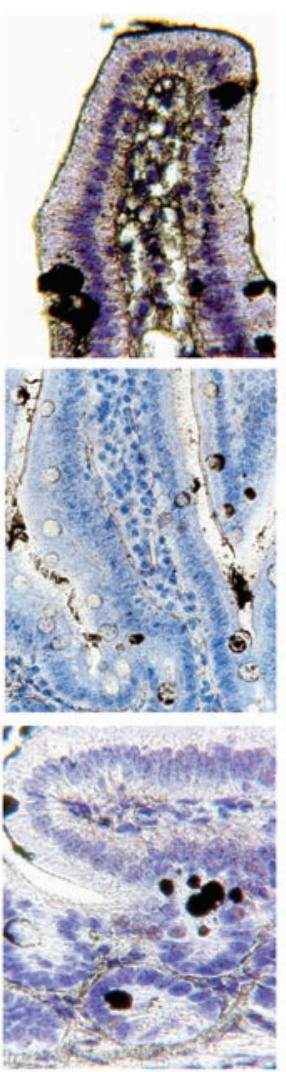

C

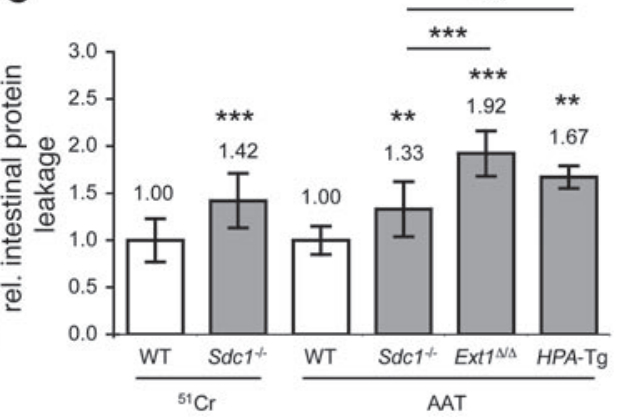

HS
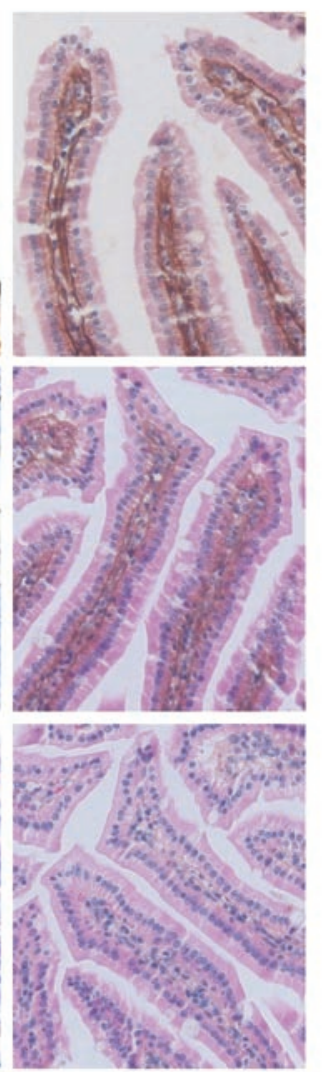

AAT

\section{Figure 2}

Loss of Sdc1 or HS causes increased intestinal protein leakage in mice (A) Sulfated GAG staining with colloidal gold (left and middle columns) and HS staining with bFGFbiotin probe (right column) in small intestinal sections from wild-type (top row), $S d c 1^{-l-}$ (middle row), and Ext1 $1^{\Delta / \Delta}$ mice (bottom row). The middle column is a magnification of the left column. Original magnification, $\times 100$ (left column); $\times 400$ (middle column); $\times 200$ (right column). (B) HS staining intensity on basolateral surface of IEC in Sdc1-/- and Ext1 ${ }^{\mathrm{\Delta} / \Delta}$ mice relative to wild-type controls. (C) Intestinal protein leakage $\left({ }^{51} \mathrm{Cr}\right.$ or AAT) in $S d c 1^{--}$, Ext $1^{\Delta / \Delta}$, and HPA-Tg mice relative to respective littermate controls. All data represent assessment in a minimum of $n=5$ mice (mean \pm SD). ${ }^{* \star} P<0.01,{ }^{* * *} P<0.001$.

Intestinal protein leakage increased within 24 hours, reached a maximum after 48 hours, and then slowly decreased, reaching baseline levels after 6-7 days (Figure 3A). Recombinant mouse TNF- $\alpha$ (rmTNF- $\alpha$ ) gave similar effects as rhTNF- $\alpha$ (data not shown). rhTNF- $\alpha$ and recombinant mouse TNF- $\alpha$ (rmTNF- $\alpha$ ) have a very similar affinity for TNFR1, but rhTNF- $\alpha$ does not bind to murine TNFR2 (40), indicating that protein leakage is mostly mediated through TNFR1 signaling.

TNF- $\alpha$-induced leakage further increased in $S d c 1^{-/-}$ mice. The combined effects of Sdc1 loss and TNF- $\alpha$ injections were synergistic (Figure 3 , A and C), consistent with our in vitro results. For example, in wild-type mice, protein leakage increased $3.25 \pm 0.76$-fold 48 hours after injection of rhTNF- $\alpha$ (Figure 3C). Theoretically, the individual effects of Sdc1 loss and TNF- $\alpha$ presence together would predict a 3.84-fold increase in protein leakage in $S d c 1^{-1-}$ mice, but we measured a $4.62 \pm 0.29$-fold increase, which indicated that these factors worked synergistically.

Exogenous rhTNF- $\alpha$ or rmTNF- $\alpha$ were cleared from mouse plasma by more than $99 \%$ within 8 hours following injection (data not shown; the reported half-life is <20 min; ref. 39), and protein leakage only increased for a few days without causing any clinical signs of PLE, i.e., hypoalbuminemia or edema. More sustained protein leakage was observed when we injected

A and B), and basal fecal AAT levels were increased (Figure 2C). $S d c 1^{-/-}$and $E x t 1^{\Delta / \Delta}$ mice did not exhibit proteinuria or hypoalbuminemia. Gross intestinal phenotype and histology appeared normal in both lines.

Mice (HPA-Tg) overexpressing human heparanase, which selectively cleaves HS and causes a significant shortening of HS chains in organs (37), present with proteinuria (38), and we found they also show a $1.67 \pm 0.12$-fold increase in fecal AAT levels compared with wild-type littermates (Figure 2C). Notably, protein leakage was significantly higher in $E x t 1^{\Delta / \Delta}$ and $H P A-T g$ mice than in $S d c 1^{-/-}$mice.

TNF- $\alpha$ induces intestinal protein leakage in vivo, which is further enhanced in $\mathrm{Sdc1}^{-1-}$ mice. PLE onset in patients is associated with moderately increased TNF- $\alpha$ levels (14), and TNF- $\alpha$ induces protein leakage in vitro $(9,11)$. To address whether TNF- $\alpha$ causes intestinal protein leakage in mice, we injected wild-type mice with a single dose of recombinant human TNF- $\alpha$ (rhTNF- $\alpha ; 0.1 \mathrm{mg} / \mathrm{kg}$, i.v.). These low doses were shown not to cause inflammation or necrosis (39).
TNF- $\alpha$ every 48 hours at higher concentrations $(0.25 \mathrm{mg} / \mathrm{kg})$ (Figure $3 \mathrm{~B}$ ). Effects on protein leakage progressively decreased, which is in accordance with observations that rats develop a partial tolerance to daily rhTNF- $\alpha$ injections (39). Plasma albumin levels in the mice remained normal, and there were no signs of edema.

IFN- $\gamma$ upregulates TNFR 1 and amplifies TNF- $\alpha$-induced leakage, which is further enhanced in Sdc1-/- mice. PLE onset in patients is often associated with increased IFN- $\gamma$ levels (13). We previously showed in HT29 cells that 12 hours of exposure to IFN- $\gamma$ upregulates TNFR1 expression and amplifies TNF- $\alpha$-induced protein leakage (11). We now assessed the effects of IFN- $\gamma$ on protein leakage in mice. Injecting rmIFN- $\gamma$ was reported to have no apparent effect on mouse intestinal architecture and histology over a wide concentration range $(0.005-5.0 \mathrm{mg} / \mathrm{kg})(39)$. We injected rmIFN- $\gamma(0.2 \mathrm{mg} / \mathrm{kg}$, i.v. $)$ and measured no increase in protein leakage. We then assessed whether IFN- $\gamma$ amplified TNF- $\alpha-$ induced leakage by injecting rmIFN- $\gamma(0.2 \mathrm{mg} / \mathrm{kg}$, i.v. $) 12$ hours 
A

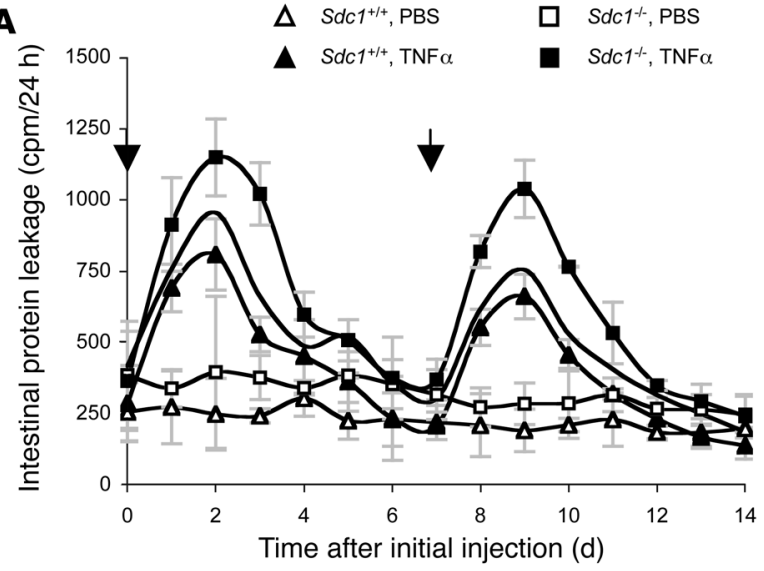

C

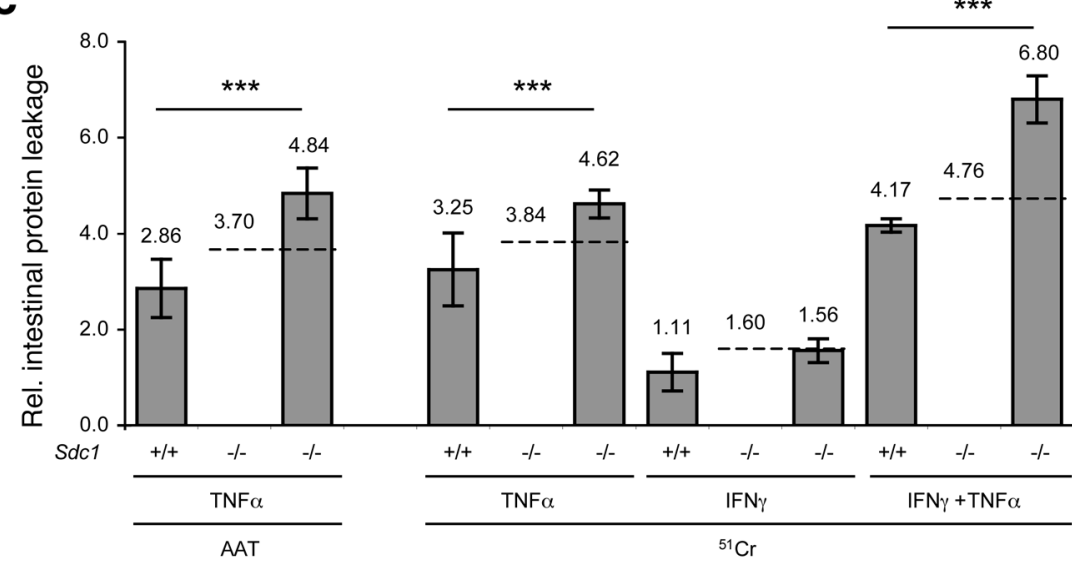

B

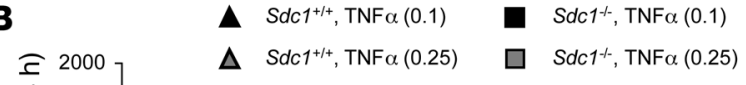

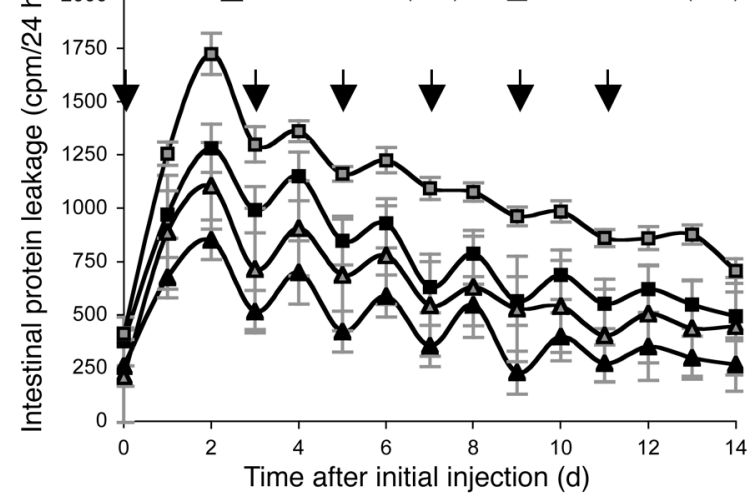

D

Figure 3

$S d c 1^{-/-}$mice are more susceptible to cytokine-induced intestinal protein leakage. (A and B) Intestinal protein leakage $\left({ }^{51} \mathrm{Cr}\right)$ in $\mathrm{S} d c 1^{+/+}$and $S d c 1^{-1-}$ mice in response to single (A) or multiple (B) i.v. injections of TNF- $\alpha$ (arrows) at 0.1 or $0.25 \mathrm{mg} / \mathrm{kg}$. Line without symbols in $\mathbf{A}$ represents predicted leakage in Sdc1 $1^{-/-}$mice if effects of Sdc1 loss and TNF- $\alpha$ exposure were additive. (C) Intestinal protein leakage (AAT or ${ }^{51} \mathrm{Cr}$ ) in Sdc1 ${ }^{+/+}$ and Sdc1-l- mice $48 \mathrm{~h}$ after exposure to TNF- $\alpha$ (i.v. $0.1 \mathrm{mg} / \mathrm{kg}$ ), IFN- $\gamma$ (i.v. $0.2 \mathrm{mg} / \mathrm{kg}$ ), or a combination of both, relative to basal leakage in $S d c 1^{+/+}$mice. Dashed lines represent predicted leakage in Sdc1-/- if effects of Sdc1 loss, TNF- $\alpha$, and/or IFN- $\gamma$ were additive. (D) FACS analysis (median fluorescent activity \pm SD) of TNFR1 expression in SGLT1-positive IEC from Sdc1 $1^{++}$or Sdc1-/- mice in response to IFN- $\gamma$ exposure relative to basal expression in $S d c 1^{+/+}$(which was set at 1.0; data not shown) mice. All data represent assessment in a minimum of $n=3$ mice. ${ }^{* \star} P<0.01,{ }^{* \star \star} P<0.001$.

prior to injecting TNF- $\alpha(0.1 \mathrm{mg} / \mathrm{kg}$, i.v. $)$. Intestinal protein leakage increased $4.17 \pm 0.14$-fold 48 hours after TNF- $\alpha$ injection, which was significantly higher than after TNF- $\alpha$ exposure alone, without prior IFN- $\gamma$ injection. Calculating the additive effects of Sdc1 loss, IFN- $\gamma$, and TNF- $\alpha$, we predicted a 4.76 -fold increase in protein leakage but actually measured a $6.80 \pm 0.49$-fold increase in protein leakage $S \mathrm{dc1}^{-/-}$mice after IFN- $\gamma$ and TNF- $\alpha$ injections, again showing synergism. FACS analysis of SGLT1-positive IEC revealed that IFN- $\gamma$ exposure increased TNFR1 expression $2.4 \pm 0.2$-fold and $3.0 \pm 0.4$-fold in wild-type and $S d c 1^{-1-}$ mice $(P<0.01)$, respectively (Figure 3D), showing the importance of HS(PG) for regulating IFN- $\gamma$-induced TNFR1 expression.

Pressure induces protein leakage ex vivo and synergizes with the effects of Sdc1 loss and cytokines. Mesenteric hypertension is common in PLE patients $(4-6,18)$. Our in vitro data showed that increased hydrostatic pressure alone causes protein leakage, which is further amplified by HS loss, IFN- $\gamma$, and TNF- $\alpha$ (11). To address whether increased pressure causes protein leakage in mice, we mounted stripped mucosal explants (consisting of epithelial cells, lamina propria, and muscularis mucosa but not circular and longitudinal muscle layers and serosa) in Ussing chambers and applied a hydrostatic pressure difference to the serosal side. Pressure alone increased albumin flux $6.9 \pm 1.0$-fold and $10.9 \pm 1.4$-fold in wild-type and $\mathrm{Sdc1} 1^{-/-}$mice, respectively, indicating that Sdc1 loss increases the susceptibility to pressure-induced leakage (Figure 4). Injecting mice with TNF- $\alpha(0.1 \mathrm{mg} / \mathrm{kg}$, i.v. $) 24$ hours prior to preparing explants increased flux $1.8 \pm 0.4$-fold and $3.8 \pm 0.5$-fold in wild-type and $S d c 1^{-/-}$mice, respectively, confirming that $\mathrm{Sdc} 1$ loss amplifies TNF- $\alpha$-induced leakage. IFN- $\gamma$ alone had no effect on albumin flux but significantly increased TNF- $\alpha$-induced leakage when administered 12 hours prior to TNF- $\alpha$ injection, which was further enhanced in $S d c 1^{-/-}$mice, confirming previous results. TNF- $\alpha$ alone or in combination with IFN- $\gamma$ exacerbated pressureinduced protein leakage. The combination of IFN- $\gamma$, TNF- $\alpha$, and pressure increased albumin flux $15.2 \pm 1.3$-fold in wild-type mice but $25.3 \pm 1.8$-fold in $S d c 1^{-/}$mice, again demonstrating the cen- 


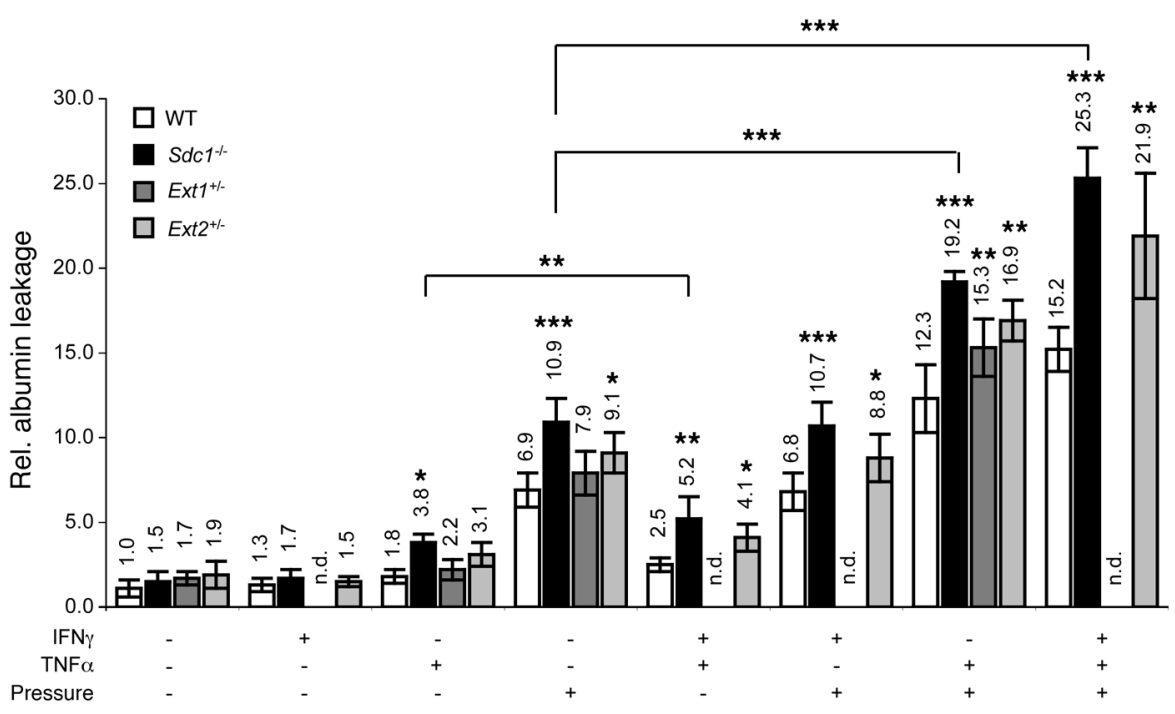

\section{Figure 4}

Sdc1 loss and Ext1 or Ext2 haploinsufficiency increase protein leakage ex vivo. Albumin leakage (mean \pm SD) through stripped mouse mucosal explants mounted in Ussing chambers. Significances calculated compared with wild-type mice with the same interventions. All data represent assessment in a minimum of $n=6$ mice. ${ }^{\star} P<0.05,{ }^{* *} P<0.01,{ }^{* * *} P<0.001$. n.d., not determined. tral role of Sdc1 in PLE pathogenesis. A similar fold increase in enteric protein loss was measured in PLE patients. Mice systemically haploinsufficient for either Ext1 $\left(E x t 1^{+/-}\right)$or Ext2 $\left(E x t 2^{+/-}\right)$ also were more susceptible to IFN- $\gamma / \mathrm{TNF}-\alpha$ - and/or pressureinduced protein leakage, but the effects were not as prominent as in $S d c 1^{1 /-}$ mice.

This ex vivo system showed that weak HS(PG) expression and IFN- $\gamma /$ TNF- $\alpha$, both alone and in combination, make the intestinal epithelial barrier more susceptible to pressure-induced leakage. To study the long-term effects of increased pressure, mesenteric hypertension would need to be increased in vivo. Mice with induced portal vein stenosis showed a significant increase in fecal AAT approximately 10 days after surgery, and AAT remained elevated for at least 2 weeks (data not shown).

$H S(P G)$ loss alone does not induce paracellular leakage. HS(PG) loss caused protein leakage and amplified IFN- $\gamma /$ TNF- $\alpha$-induced protein leakage in vitro and in mice. However, how HS(PG) loss contributes to protein leakage is unknown. To assess whether $\mathrm{HS}(\mathrm{PG})$ loss increases paracellular leakage, we harvested mouse intestines in lanthanum buffer followed by phosphate precipitation (41). Lanthanum did not pass the junctional complex, and the extracellular space between adjacent epithelial cells was void of lanthanum precipitates in wild-type mice (Figure 5A) but also in $S d c 1^{-/}$mice (Figure 5B). These results indicate that $\mathrm{HS}(\mathrm{PG})$ deficiency alone has no effect on paracellular leakage. Sections from mice exposed to IFN- $\gamma /$ TNF- $\alpha$ showed lanthanum passing the junctional complex and appearing in the interepithelial space and all the way down to the basal surface (Figure 5, C-E). These results confirm that IFN- $\gamma /$ TNF- $\alpha$ alter junctional complex integrity and impair intestinal epithelial barrier function.

Heparin and 2/3-DS-H alleviate cytokine-induced protein leakage. Heparin injections $(100-500 \mathrm{U} / \mathrm{kg})$ mitigate PLE in some post-Fontan patients (25-27) but have side effects mostly resulting from anticoagulant activity $(27,30)$. We screened a library of non-anticoagulant heparin-like compounds and other GAG derivatives for their ability to reduce IFN- $\gamma /$ TNF- $\alpha$-induced leakage in vitro (Figure 6A). Inhibition depended on molecular size (Figure 6A, lanes 3-7). Shorter fragments (degree of polymerization 2 [dp 2], lane 4) had almost no effect, whereas longer fragments (dp 20, lane 7) reduced IFN- $\gamma /$ TNF- $\alpha$-induced leakage by more than $50 \%$. Low- molecular-weight heparin (lane 3) was much less effective than high-molecular-weight heparin (lane 2), supporting clinical data that low-molecular-weight heparin does not mitigate PLE (26). Heparin lost some of its activity after removal of 2-, 3-, and/or, 6-O-sulfates (lanes 8-11), reduction of the carboxyl group (lane 12 ), or substitution of $N$-sulfates with $N$-acetyl group (lanes 13 and 14). Other GAGs such as chondroitin, dermatan, or acharan sulfate (lanes 15-20) also slightly reduced IFN- $\gamma /$ TNF- $\alpha$-induced leakage. Sulfated cyclodextran (lane 21) or sucrose octasulfate (lane 22) had no effect. Next to unfractionated, high-molecularweight heparin, non-anticoagulant 2/3-DS-H (lane 9) was most efficient in reducing IFN- $\gamma /$ TNF- $\alpha$-induced leakage.

We then assessed whether heparin or $2 / 3-\mathrm{DS}-\mathrm{H}$ also reduce IFN- $\gamma /$ TNF- $\alpha$-induced protein leakage in mice by giving daily i.v. injections of either heparin or 2/3-DS-H. Three days after the initial injection, we administered either TNF- $\alpha$ alone or a combination of IFN- $\gamma$ and TNF- $\alpha$, as described above. Daily injections of heparin or $2 / 3-\mathrm{DS}-\mathrm{H}$ continued for 7 days. Low doses of either heparin $(100 \mathrm{U} / \mathrm{kg}, 0.7 \mathrm{mg} / \mathrm{kg})$ or $2 / 3-\mathrm{DS}-\mathrm{H}(0.7 \mathrm{mg} / \mathrm{kg})$ reduced cytokine-induced intestinal protein leakage by more than $50 \%$ (Figure 6, B and E). Heparin doses 5-fold higher (500 U/kg, 3.5 $\mathrm{mg} / \mathrm{kg}$ ) completely prevented leakage (Figure 6, C and F) in wildtype mice. In $\mathrm{S} d c 1^{-/-}$mice, higher $2 / 3-\mathrm{DS}-\mathrm{H}$ doses $(3.5 \mathrm{mg} / \mathrm{kg})$ completely prevented TNF- $\alpha$-induced leakage (Figure 6D) and reduced IFN- $\gamma /$ TNF- $\alpha$-induced leakage by more than $85 \%$ (Figure $6 \mathrm{G})$. Administration of either heparin or $2 / 3-\mathrm{DS}-\mathrm{H}$ alone for 10 consecutive days had no adverse effects on mice and did not alter basal intestinal protein loss.

\section{Discussion}

Our in vitro and in vivo results show that HSPGs are essential for maintaining the intestinal epithelial barrier function. Progressive loss of HSPGs increases basal protein leakage. The greater the HS loss, the higher the leakage. This deficiency exacerbates cytokineand pressure-induced intestinal protein leakage, but heparin and non-anticoagulant $2 / 3$-DS-H prevent protein leakage, providing a rationale for heparin therapy in PLE patients.

Although HSPG loss appears to play a central role in PLE pathogenesis, the etiology of HSPG loss in PLE patients remains unknown. We hypothesize that one or more environmental insults 


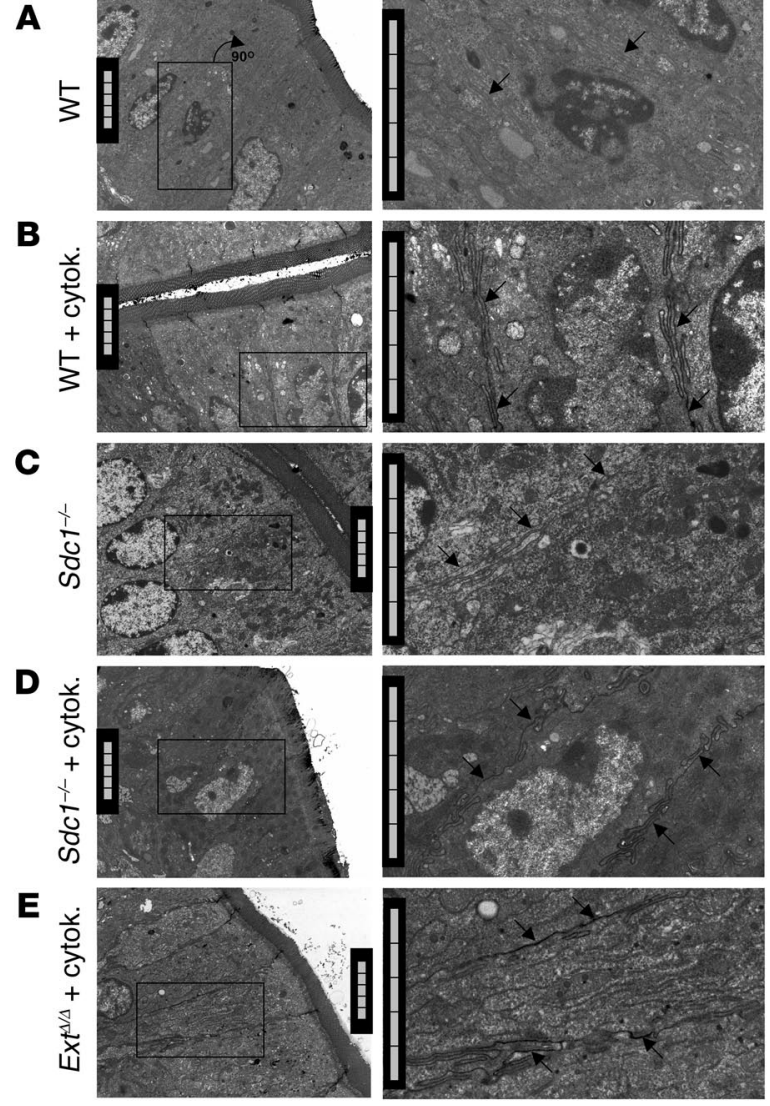

such as infections, inflammation, or increased mesenteric pressure collide with genetic insufficiencies in pathways associated with HSPG biosynthesis, trafficking, or degradation (10). Here we tested this hypothesis by using an extreme approach of genetically ablating either Sdc1 or intestinal epithelial Ext1, which is unlikely to occur in PLE patients. However, even mice haploinsufficient for either Ext1 or Ext2 also show an increased susceptibility for stress-induced protein leakage. Thus the risk of developing PLE could increase if an individual had several haploinsufficient mutations affecting overall HSPG expression. Environmental insults may then further exacerbate HSPG loss. TNF- $\alpha$, for example, downregulates HSPG expression (42) and also induces HSPG shedding (43). Inducing systemic hypertension in rats reduces HSPG expression in the glomeruli and causes proteinuria (44). We also have evidence that increased pressure reduces Sdc1 mRNA levels in HT29 cells (our unpublished results). Therefore, low levels of HSPG expression in genetically susceptible individuals may be further diminished below a critical threshold by cytokines and pressure. In return, reduced HSPG expression amplifies the effects of cytokines and pressure, creating a vicious cycle of more dramatic HSPG loss, breakdown of the intestinal epithelial barrier, and, eventually, PLE.

However, why HSPG loss alone increases intestinal epithelial leakage remains elusive. Here we show by electron microscopic examination on lanthanum-bathed intestinal tissues that HSPG loss alone does not increase paracellular flux between adjacent epithelial cells. If this is the case, how does protein leak across the intestinal epithelium if the junctional complex integrity remains intact? Watson et al. asked a slightly different question (45): How

\section{Figure 5}

Sdc1 loss alone does not increase paracellular leakage. Electron micrographs of mouse intestinal epithelium bathed in lanthanum. Lateral intercellular spaces were void of lanthanum phosphate precipitates (arrows) in wild-type (A) and $S d c 1^{-1-}$ mice (C) without cytokine exposure but filled with lanthanum phosphate precipitates in wild-type (B), Sdc1-1- (D), and Ext1 $1^{\Delta / \Delta}$ mice (E) after IFN- $\gamma /$ TNF- $\alpha$ exposure. Right column is a magnification of boxed areas in the left column. Scale bars: $5 \mu \mathrm{m}$.

does the epithelial barrier remain intact despite continuous cell shedding? They showed that an impermeable substance completely fills the void left by shedded cells and speculated that this sealing substance could be HS secreted by neighboring epithelial cells and/or myofibroblasts (45). HS(PG) deficiency would result in an inability to seal the gaps and, as a consequence, cause leakage. Further studies are needed to test this hypothesis and show whether HS is indeed the sealing agent.

From a therapeutic perspective, the vicious cycle involving HSPG loss, cytokines and pressure can be interrupted at multiple steps by addition of heparin or 2/3-DS-H, compensating for the loss of cellassociated HS and restoring the IFN- $\gamma /$ TNF- $\alpha$-quenching effect. Soluble heparin binds to both IFN- $\gamma$ and TNF- $\alpha$, just as cell-associated HS does $(28,29)$, and blocks IFN- $\gamma /$ TNF- $\alpha$-induced protein leakage in vitro $(9,11)$ and, as we show here, in mice. This may be one explanation for the curious beneficial effects of heparin injections in some post-Fontan patients with PLE (25-27). However, heparin has undesirable side effects due to its anticoagulant activity $(27,30)$. Partially removing heparin's 2 - and $3-O$ sulfates reduces its anticoagulant activity by about $90 \%$, while other biological activities remain intact (46). Here we show that $2 / 3-\mathrm{DS}-\mathrm{H}$, similar to unmodified heparin, prevents IFN- $\gamma / \mathrm{TNF}-\alpha-$ induced protein leakage in vitro and in mice. Its greatly reduced anticoagulant activity may mean that it can be used safely at much higher doses than unmodified heparin. Clinical trials will be needed to assess whether 2/3-DS-H can be considered a safe and effective therapeutic option for patients suffering and dying from PLE.

\section{Methods}

Measurement of protein flux in vitro. Human intestinal epithelial HT29 cells (ATCC no. HTB-38) were grown in Dulbecco's modified Eagle's medium (Irvine Scientific) supplemented with $10 \%$ fetal calf serum (HyClone), penicillin, streptomycin, and L-glutamine. Cells were grown on semipermeable inserts $(1.0 \mu \mathrm{m}$ pore size; Becton Dickinson) for 5 days until they reached confluence (9). Integrity of the monolayer before and after interventions was monitored by measuring TER with an epithelial voltohmmeter and STX2 electrodes (World Precision Instruments). TER in the untreated confluent HT29 monolayer was defined as $100 \%$ after correcting for the resistance of the semipermeable membrane in tissue culture media but without cells. To assess protein leakage across the monolayer, albuminFITC $(400 \mu \mathrm{g} / \mathrm{ml}$; Sigma-Aldrich) was added to the inserts. Albumin-FITC concentration in the well (across the monolayer) was measured after $1 \mathrm{~h}$ using a spectrophotometer. Albumin flux through the untreated confluent monolayer was defined as 1.0.

Sdc1 siRNA knockdown and induction of HS loss. HT29 cells were transfected with Sdc1 siRNA1 (CCAUUCUGACUCGGUUUCUTT), Sdc1 siRNA2 (GCCAAGGUUUUAUAAGGCUTT), or scrambled siRNA (all Ambion) as negative control using siLentFect Lipid (BioRad). Sdc1 mRNA levels were measured by quantitative PCR 5 days after transfection. To induce loss of cell-associated HS, HT29 cells were incubated with HSase $(0.6 \mathrm{mU} / \mathrm{ml}$; 

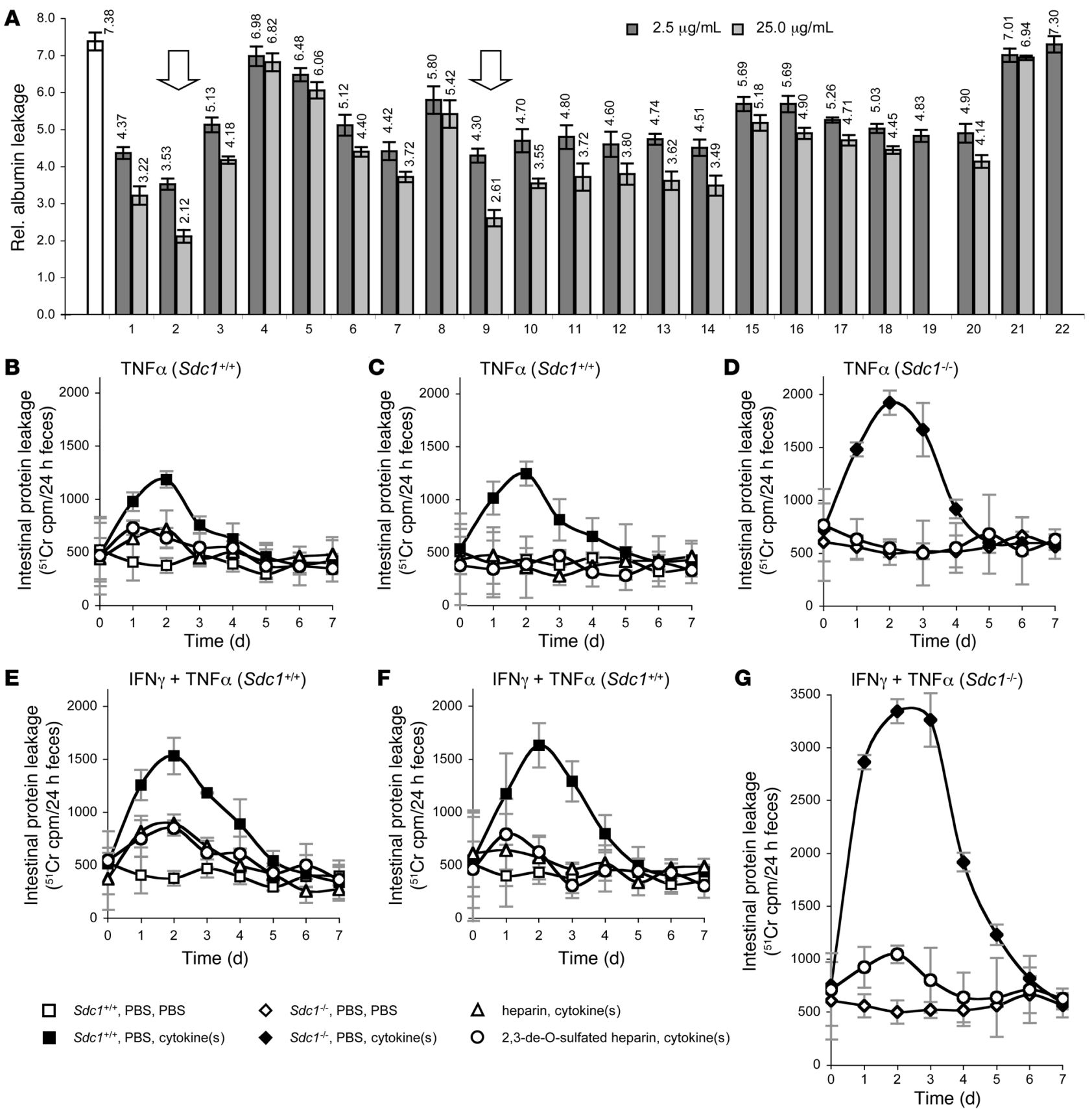

Figure 6

Heparin and 2/3-DS-H alleviate protein leakage in vitro and in mice. (A) Albumin leakage (mean \pm SD) through HT29 monolayers relative to untreated cells. Maximum leakage (white bar) was induced by incubating cells with heparinase (HS loss), IFN- $\gamma$ (10 ng/ml, $24 \mathrm{~h}$ ), and TNF- $\alpha$ $(2 \mathrm{ng} / \mathrm{ml}, 12 \mathrm{~h})$. Cytokines were coincubated with heparin-like compounds or other GAG derivatives at $2.5 \mu \mathrm{g} / \mathrm{ml}$ or $25.0 \mu \mathrm{g} / \mathrm{ml}$. Heparin (lane 2) and 2/3-DS-H (lane 9) were most effective in alleviating cytokine-induced protein leakage (arrows). Lane 1, HS; lane 2, high-molecular-weight heparin (unfractionated); lane 3, low-molecular-weight heparin; lane 4, sized heparin, dp 2; lane 5, sized heparin, dp 8; lane 6, sized heparin, dp 14; lane 7, sized heparin, dp 20; lane 8, 2,6-de-O-sulfated heparin; lane 9, 2/3-DS-H; lane 10, 6-O-desulfated heparin (chemical desulfation); lane 11, 6-O-desulfated heparin (enzymatic desulfation with endosulfatase [HSulf2]); lane 12, carboxyl-reduced heparin; lane 13, fully $N$-acetylated heparin; lane 14, fully $\mathrm{O}$-sulfated $\mathrm{N}$-acetylated heparin; lane 15 , chondroitin sulfate; lane 16 , fully $\mathrm{O}$-sulfated chondroitin sulfate; lane 17 , dermatan sulfate; lane 18 , fully $O$-sulfated dermatan sulfate; lane 19, fully $O$-sulfated hyaluronic acid; lane 20 , archaran sulfate; lane 21 , sulfated cyclodextran; lane 22, sucrose octasulfate. (B-G) Intestinal protein leakage in Sdc1 $1^{+/+}$(B, C, E, and F) and Sdc1 $1^{-/}$mice (D and G) assessed by in vivo ${ }^{51} \mathrm{Cr}$ labeling. Mice were injected daily with low $(100 \mathrm{U} / \mathrm{kg}, 0.7 \mathrm{mg} / \mathrm{kg})(\mathbf{B}$ and $\mathbf{E})$ or high doses $(500 \mathrm{U} / \mathrm{kg}, 3.5 \mathrm{mg} / \mathrm{kg})$ of heparin $(\mathbf{C}$ and $\mathbf{F})$, 2/3-DS-H (C, D, F, and G), or PBS as control. Three days following the first injections $(t=0)$, intestinal protein leakage was induced by injection of either TNF- $\alpha$ (i.v., $0.1 \mathrm{mg} / \mathrm{kg}$ ) (B-D) or IFN- $\gamma$ (i.v., $0.2 \mathrm{mg} / \mathrm{kg}$ ) and TNF- $\alpha$ (i.v., $0.1 \mathrm{mg} / \mathrm{kg}, 12 \mathrm{~h}$ after IFN- $\gamma$ ) (E-G). PBS was used as a control. All data represent assessment in a minimum of $n=4$ mice (mean $\pm \mathrm{SD}$ ). 
Sigma-Aldrich) for at least $1.5 \mathrm{~h}$. To suppress reappearance of cell-associated HS, cells were incubated with $\beta$-xyloside ( $\mathrm{p}$-nitrophenyl- $\beta$-D-xylopyranoside, $100 \mu \mathrm{M}$; Sigma-Aldrich), which competes out GAG chain synthesis on core proteins.

Measurement of cell-associated GAGs. HT29 cells were incubated with $\mathrm{Na}_{2}{ }^{35} \mathrm{SO}_{4}(100 \mu \mathrm{Ci} / \mathrm{ml})$ for $8 \mathrm{~h}$. Cells were harvested in $4 \mathrm{M}$ guanidine $\mathrm{HCl} / 50 \mathrm{mM}$ acetic acid/1\% Triton X-100 and diluted with 50 volumes of $6 \mathrm{M}$ urea/50 mM acetic acid/1\% Triton X-100. Radiolabeled proteoglycans/ GAGs were purified by anion exchange chromatography on DE53 columns (Whatman) as described previously (9). Radioactivity was determined by liquid-scintillation counting.

Mice. Sdc1/- mice were provided by Merton Bernfield (Harvard Medical School, Boston, Massachusetts, USA) (47) and bred for more than 12 generations onto a $\mathrm{C} 57 \mathrm{BL} / 6$ genetic background. $S d c 1^{-/-}$mice were genotyped as previously described (47). Homozygous transgenic mice overexpressing human heparanase (HPA-Tg) were generated and genotyped as described (38). The HPA-Tg mice were on a mixed genetic background. Results from these mice were compared with those of control animals with the same genetic background. Ext1 $1^{+/-}$and $E x t 2^{+/-}$mice (48), backcrossed on a C57BL/6 genetic background, were provided by Jeffrey Esko (University of California, San Diego, La Jolla, California, USA) and genotyped as previously described (48). Mice with an intestine-specific Ext1 knockout were generated by crossing Ext $1^{f l o x} /$ flox mice provided by Yu Yamaguchi (Burnham Institute for Medical Research, La Jolla, California, USA) (49) with VillinCre mice (Vil-Cre; The Jackson Laboratory) expressing Cre recombinase under the control of the 12.4-kb Villin promoter, which drives exclusively in the intestinal epithelium starting at day E12.5. (50). Penetrance of Cre expression in these tissues is almost $100 \%(50)$. Both Ext $1^{\text {flox } / \text { flox }}$ and Villin-Cre mice were on a C57BL/ 6 genetic background. Ext $1^{\Delta / \Delta}$ mice were genotyped as previously described (49). To exclude age and gender effects, all experiments were performed on 3- to 4-month-old male mice. Unless otherwise indicated, wild-type littermates were used as controls. All mouse work was approved by the Animal Research Committee at the Burnham Institute for Medical Research.

Measurement of protein flux through stripped mouse mucosal explants. Mice were euthanized, and small intestines were immediately excised and rinsed in oxygenized Ringer solution containing $10 \mathrm{mM}$ glucose. Intestines were opened along the mesenteric lining. Serosa, longitudinal, and circular muscle layers were stripped off. The remaining mucosal layer (including muscularis mucosa, lamina propria, and epithelial cells) was mounted into Ussing chambers. Both sides of the tissue were bathed in Ringer's solution gassed with $95 \% \mathrm{O}_{2}$ and $5 \% \mathrm{CO}_{2}$. Hydrostatic pressure difference was induced by adding additional buffer volume to the compartment facing the serosal tissue side (10). Protein leakage across the tissue was determined by measuring flux of albumin-FITC from the serosal to the mucosal side. Albumin flux through tissues from wild-type mice without further intervention was defined as 1.0. Prior to preparing mucosal explants, some mice were injected with either rmIFN- $\gamma(0.2 \mathrm{mg} / \mathrm{kg}$, i.v., RND), rhTNF- $\alpha$ $(0.1 \mathrm{mg} / \mathrm{kg}$, i.v., RND), or a combination of both.

Intestinal protein leakage in mice. Two independent methods were used to assess intestinal protein leakage in mice. (a) ${ }^{51} \mathrm{CrCl}_{3}(300,000 \mathrm{cpm})$ was injected in the tail vein to label plasma albumin. Radioactivity of 24-h feces samples was measured with a gamma counter (10). Fecal excretion correlates with intestinal protein leakage (34). (b) AAT levels in 24-h feces samples were determined by competitive ELISA (10).

Immunohistochemistry: sulfated GAG staining. Sulfated GAG distribution was localized on formalin-fixed tissues as previously reported $(22,51)$. Briefly, cationic colloidal gold (polylysine gold; Biocell International) was suspended 1:100 in PBS at $\mathrm{pH} 1.2$ and applied to the tissue sections for $1 \mathrm{~h}$ at room temperature. Bound polylysine gold was visualized with a silver enhancer. Tissue sections were counterstained with Mayer's hemalum and mounted with Aquamount.

Immunohistochemistry: HS staining with biotinylated FGF. FGF was biotinylated as previously described (52). Briefly, FGF2 $(0.5 \mathrm{mg}$, E. coli recombinant material; Selective Genetics Inc.) was protected with heparin (0.4 $\mathrm{mg}$ ) in $0.2 \mathrm{M}$ HEPES buffer ( $\mathrm{pH}$ 8.4) and mixed with biotin hydrazide (long arm, water-soluble, $40 \mu \mathrm{g}$; Pierce Biotechnology) in a final volume of $0.2 \mathrm{ml}$. After $2 \mathrm{~h}$ at room temperature, $40 \mu \mathrm{lof} 10 \mathrm{mg} / \mathrm{ml}$ glycine solution was added to stop the reaction. The sample was diluted with $30 \mathrm{ml}$ of $20 \mathrm{mM}$ HEPES buffer ( $\mathrm{pH} 7.4$ ) containing $0.5 \mathrm{M} \mathrm{NaCl}$ and $0.2 \% \mathrm{BSA}$ and loaded onto a 1-ml column of heparin-Sepharose CL-6B (Amersham Pharmacia Biotech). The column was washed with $30 \mathrm{ml}$ of buffer and eluted with $2.5 \mathrm{ml}$ of solution adjusted to $3 \mathrm{M} \mathrm{NaCl}$. The sample was desalted on a PD-10 column (Amersham Pharmacia Biotech) equilibrated with $20 \mathrm{mM}$ HEPES buffer ( $\mathrm{pH}$ 7.4) containing $0.2 \%$ BSA. Inclusion of ${ }^{125}$ I-FGF2 ( $~ \AA \AA ̊, \sim 10^{5} \mathrm{cpm}$; ref. 48$)$ showed that the overall recovery of material was $30 \%-40 \%$. Paraffin-embedded small intestine tissue sections were labeled with the FGF-biotin probe $(40 \mu \mathrm{g} / \mathrm{ml}$, overnight, $4^{\circ} \mathrm{C}$ ), as previously described (53). Bound factor was detected with HRP-conjugated streptavidin (1:500, $30 \mathrm{~min}$ at room temperature; Jackson ImmunoResearch Laboratories). To determine staining density, ImageJ software was used on digital photomicrographs, using plug-ins for color deconvolution (A.C. Ruifrok, Netherlands Forensic Institute, The Hague, The Netherlands) and region-of-interest densitometry (J. Kuhn, University of Texas, Austin, Texas, USA; Anthony Padua, Duke University, Greensboro, North Carolina, USA). Mean density scores were obtained for each slide from multiple villous tip epithelial basolateral membranes. A staining density index was derived from reciprocals of light transmission, minus background constant, but all statistical analysis was performed on unprocessed data.

Electron microscopy. Mouse small intestines $(5-10 \mathrm{~mm})$ were dissected and fixed for $3 \mathrm{~h}$ at room temperature in a buffer containing $4 \%$ paraformaldehyde, $1.5 \%$ glutaraldehyde (in $0.1 \mathrm{M}$ cacodylate buffer), and $1 \%$ lanthanum nitrate hexahydrate, followed by an additional $5 \mathrm{~h}$ in a buffer containing $3 \%$ glutaraldehyde (in $0.1 \mathrm{M}$ cacodylate buffer) and $1 \%$ lanthanum nitrate hexahydrate. To precipitate lanthanum, tissues were incubated overnight with a $0.2-\mathrm{M}$ phosphate buffer at $4^{\circ} \mathrm{C}$. Tissues were postfixed for $2 \mathrm{~h}$ at room temperature in $1 \% \mathrm{OsO}_{4}$ with $0.15 \%$ ferricyanide in $0.1 \mathrm{M}$ cacodylate buffer, washed for $1 \mathrm{~h}$ in $0.1 \mathrm{M}$ cacodylate buffer, and dehydrated in 50\%, 70\%, 90\%, and 100\% ethanol for 15 min each. Tissues were cleared in 2 changes of propylene oxide for $15 \mathrm{~min}$ and then impregnated overnight in Epon/Araldite resin. Afterward, samples were embedded and polymerized at $60^{\circ} \mathrm{C}$. Thick sections $(0.5-2.0 \mu \mathrm{m})$ were stained in toluidine blue for general evaluation. Afterward, thin sections $(60 \mathrm{~nm})$ were cut and mounted on parlodion-coated copper slot grids. Sections were stained with uranyl acetate and lead citrate and analyzed at 3,900-fold magnification.

FACS analysis and TNFR1 expression. Mouse IEC were harvested as previously described (54). Cells were stained with anti-TNFR1-specific (Santa Cruz Biotechnology Inc.) and IEC-specific anti-SGLT1 antibodies (Alpha Diagnostic) and analyzed by flow cytometry (Becton Dickinson). SGLT1positive cells were gated, and median fluorescence activity for TNFR1 was recorded. Data are expressed as median fluorescence activity \pm SD relative to cells from wild-type mice without intervention.

Statistics. Data are expressed as mean \pm SD unless otherwise stated. Groups were compared by the Student's 2-tailed paired or unpaired $t$ test. A value of $P<0.05$ was considered statistically significant. Unless otherwise stated, in vitro results represent a minimum of 3 evaluations, in vivo results are obtained from a minimum of $n=3$ mice, and ex vivo data is obtained from a minimum of $n=6$ mice. 


\section{Acknowledgments}

We thank Robert J. Linhardt (Rensselaer Polytechnic Institute, Troy, New York, USA) for providing us with a heparin-like compound library, Steven Rosen and Kenji Uchimura (UCSF, San Francisco, California, USA) for providing endosulfatase-treated heparin, and Lianchun Wang (University of Georgia, Athens, Georgia, USA) for providing us with 2/3-DS-H. We thank Kim E. Barrett and Declan McCole (UCSD) for their support with preparing stripped mucosal explants and with the Ussing chamber experiments. We gratefully acknowledge the late Merton Bernfield (Harvard Medical School, Boston, Massachusetts, USA) for providing us with the $S d c 1^{-/-}$mouse line. We thank Israel Vlodavsky (Bruce Rappaport Faculty of Medicine, Technion, Israel) for the HPA-Tg mice. We thank Malcolm Woods (Director Core Microscopy Facility, The Scripps Research Institute, La Jolla, California, USA) for his excellent support with electron microscopy. We also thank Wilfred Charbono and Adriana Charbono for their excellent technical assistance with mice, Edward Monosov and Guillermina Garcia for technical assistance with immunohistochemistry, and Mien Nguyen for technical assistance with mouse genotyping. This work was supported by NIH grants (R01 DK065091 and R21 HL 078997, to H.H. Freeze; R01 HL57345 to J.D. Esko) and grants from Children's Hearts Fund (to H.H. Freeze) and Deutsche Forschungsgemeinschaft (BO-2488/1-1, to L. Bode).

Received for publication April 6, 2007, and accepted in revised form October 17, 2007.

Address correspondence to: Hudson H. Freeze, Burnham Institute for Medical Research, 10901 North Torrey Pines Road, La Jolla, California 92037, USA. Phone: (858) 646-3142; Fax: (858) 7136281; E-mail: hudson@burnham.org.
1. Ford, H.R. 2006. Mechanism of nitric oxide-mediated intestinal barrier failure: insight into the pathogenesis of necrotizing enterocolitis. J. Pediatr. Surg. 41:294-299.

2. Van Leeuwen, P.A., et al. 1994. Clinical significance of translocation. Gut. 35:S28-34.

3. Beeken, W.L., Busch, H.J., and Sylwester, D.L. 1972. Intestinal protein loss in Crohn's disease. Gastroenterology. 62:207-215.

4. Marquardt, T., and Denecke, J. 2003. Congenital disorders of glycosylation: review of their molecular bases, clinical presentations and specific therapies. Eur. J. Pediatr. 162:359-379.

5. Niehues, R., et al. 1998. Carbohydrate-deficient glycoprotein syndrome type Ib. Phosphomannose isomerase deficiency and mannose therapy. J. Clin. Invest. 101:1414-1420.

6. Westphal, V., et al. 2000. Reduced heparan sulfate accumulation in enterocytes contributes to protein-losing enteropathy in a congenital disorder of glycosylation. Am. J. Pathol. 157:1917-1925.

7. Molina, J.F., Brown, R.F., Gedalia, A., and Espinoza, L.R. 1996. Protein losing enteropathy as the initial manifestation of childhood systemic lupus erythematosus. J. Rheumatol. 23:1269-1271.

8. Mertens, L., Hagler, D.J., Sauer, U., Somerville, J., and Gewillig, M. 1998. Protein-losing enteropathy after the Fontan operation: an international multicenter study. PLE study group. J. Thorac. Cardiovasc. Surg. 115:1063-1073.

9. Bode, L., Eklund, E.A., Murch, S., and Freeze, H.H 2005. Heparan sulfate depletion amplifies TNFalpha-induced protein leakage in an in vitro model of protein-losing enteropathy. Am. J. Physiol. Gastrointest. Liver Physiol. 288:G1015-G1023.

10. Bode, L., and Freeze, H.H. 2005. Applied glycoproteomics - Approaches to study genetic-environmental collisions causing protein-losing enteropathy. Biochim. Biophys. Acta. 1760:547-559.

11. Bode, L., Murch, S., and Freeze, H.H. 2006. Heparan sulfate plays a central role in a dynamic in vitro model of protein-losing enteropathy. J. Biol. Chem. 281:7809-7815.

12. Lenz, D., et al. 2003. Protein-losing enteropathy in patients with Fontan circulation: is it triggered by infection? Crit. Care. 7:185-190.

13. Shimizu, T., et al. 2003. Enhanced production of interferon-gamma as a possible cause of proteinlosing enteropathy after modified Fontan operation. J. Pediatr. Gastroenterol. Nutr. 37:504-507.

14. Ostrow, A.M., Freeze, H., and Rychik, J. 2006. Protein-losing enteropathy after fontan operation: investigations into possible pathophysiologic mechanisms. Ann. Thorac. Surg. 82:695-700.

15. Madara, J.L., and Stafford, J. 1989. Interferongamma directly affects barrier function of cul- tured intestinal epithelial monolayers. J. Clin. Invest. 83:724-727.

16. Suenaert, P., et al. 2002. Anti-tumor necrosis factor treatment restores the gut barrier in Crohn's disease. Am. J. Gastroenterol. 97:2000-2004.

17. Fish, S.M., Proujansky, R., and Reenstra, W.W. 1999. Synergistic effects of interferon gamma and tumour necrosis factor alpha on T84 cell function. Gut. 45:191-198.

18. Marino, B.S. 2002. Outcomes after the Fontan procedure. Curr. Opin. Pediatr. 14:620-626.

19. Harms, H.K., et al. 2002. Oral mannose therapy persistently corrects the severe clinical symptoms and biochemical abnormalities of phosphomannose isomerase deficiency. Acta Paediatr. 91:1065-1072.

20. Fujii, T., et al. 2003. Fecal alpha1-antitrypsin concentrations as a measure of enteric protein loss after modified fontan operations. J. Pediatr. Gastroenterol. Nutr. 37:577-580.

21. Rychik, J., and Spray, T.L. 2002. Strategies to treat protein-losing enteropathy. Semin. Thorac. Cardiovasc. Surg. Pediatr. Card. Surg. Annu. 5:3-11.

22. Murch, S.H., et al. 1993. Disruption of sulphated glycosaminoglycans in intestinal inflammation. Lancet. 341:711-714.

23. Murch, S.H., et al. 1996. Congenital enterocyte heparan sulphate deficiency with massive albumin loss, secretory diarrhoea, and malnutrition. Lancet. 347:1299-1301.

24. Kanwar, Y.S., Linker, A., and Farquhar, M.G. 1980. Increased permeability of the glomerular basement membrane to ferritin after removal of glycosaminoglycans (heparan sulfate) by enzyme digestion. J. Cell Biol. 86:688-693.

25. Kelly, A.M., Feldt, R.H., Driscoll, D.J., and Danielson, G.K. 1998. Use of heparin in the treatment of protein-losing enteropathy after fontan operation for complex congenital heart disease. Mayo Clin. Proc. 73:777-779.

26. Donnelly, J.P., Rosenthal, A., Castle, V.P., and Holmes, R.D. 1997. Reversal of protein-losing enteropathy with heparin therapy in three patients with univentricular hearts and Fontan palliation. J. Pediatr. 130:474-478.

27. Bendayan, I., Casaldaliga, J., Castello, F., and Miro, L. 2000. Heparin therapy and reversal of proteinlosing enteropathy in a case with congenital heart disease. Pediatr. Cardiol. 21:267-268.

28. Lortat-Jacob, H., and Grimaud, J.A. 1991. Interferon-gamma binds to heparan sulfate by a cluster of amino acids located in the C-terminal part of the molecule. FEBS Lett. 280:152-154.

29. Lantz, M., Thysell, H., Nilsson, E., and Olsson, I. 1991. On the binding of tumor necrosis factor (TNF) to heparin and the release in vivo of the TNF-binding protein I by heparin. J. Clin. Invest.
88:2026-2031.

30. Bendayan, I., and Casaldaliga, J. 2002. Protein-losing enteropathy. Pediatr. Cardiol. 23:249.

31. Munro, D.R. 1974. Route of protein loss during a model protein-losing gastropathy in dogs. Gastroenterology. 66:960-972.

32. Littman, M.P., Dambach, D.M., Vaden, S.L., and Giger, U. 2000. Familial protein-losing enteropathy and protein-losing nephropathy in Soft Coated Wheaten Terriers: 222 cases (1983-1997). J. Vet. Intern. Med. 14:68-80.

33. Quigley, E.M., Ross, I.N., Haeney, M.R., Holbrook, I.B., and Marsh, M.N. 1987. Reassessment of faecal alpha-1-antitrypsin excretion for use as screening test for intestinal protein loss. J. Clin. Pathol. 40:61-66.

34. Crossley, J.R., and Elliott, R.B. 1977. Simple method for diagnosing protein-losing enteropathies. $\mathrm{Br}$. Med. J. 1:428-429.

35. Esko, J.D., and Selleck, S.B. 2002. Order out of chaos: assembly of ligand binding sites in heparan sulfate. Annu. Rev. Biochem. 71:435-471.

36. Lin, X., et al. 2000. Disruption of gastrulation and heparan sulfate biosynthesis in EXT1-deficient mice. Dev. Biol. 224:299-311.

37. Li, J.P., et al. 2005. In vivo fragmentation of heparan sulfate by heparanase overexpression renders mice resistant to amyloid protein A amyloidosis. Proc. Natl. Acad. Sci. U. S. A. 102:6473-6477.

38. Zcharia, E., et al. 2004. Transgenic expression of mammalian heparanase uncovers physiological functions of heparan sulfate in tissue morphogenesis, vascularization, and feeding behavior. FASEB J. 18:252-263.

39. Patton, J.S., et al. 1987. Development of partial tolerance to the gastrointestinal effects of high doses of recombinant tumor necrosis factor-alpha in rodents. J. Clin. Invest. 80:1587-1596.

40. Lewis, M., et al. 1991. Cloning and expression of cDNAs for two distinct murine tumor necrosis factor receptors demonstrate one receptor is species specific. Proc. Natl. Acad. Sci. U. S. A. 88:2830-2834.

41. Machen, T.E., Erlij, D., and Wooding, F.B. 1972. Permeable junctional complexes. The movement of lanthanum across rabbit gallbladder and intestine. J. Cell Biol. 54:302-312.

42. Ramasamy, S., Lipke, D.W., McClain, C.J., and Hennig, B. 1995. Tumor necrosis factor reduces proteoglycan synthesis in cultured endothelial cells. J. Cell. Physiol. 162:119-126.

43. Endo, K., et al. 2003. Cleavage of syndecan-1 by membrane type matrix metalloproteinase- 1 stimulates cell migration. J. Biol. Chem. 278:40764-40770.

44. Sasamura, H., Shimizu-Hirota, R., Nakaya, H., and Saruta, T. 2001. Effects of AT1 receptor antagonist on proteoglycan gene expression in hypertensive rats. Hypertens. Res. 24:165-172. 
45. Watson, A.J., et al. 2005. Epithelial barrier function in vivo is sustained despite gaps in epithelial layers. Gastroenterology. 129:902-912.

46. Fryer, A., et al. 1997. Selective O-desulfation produces nonanticoagulant heparin that retains pharmacological activity in the lung. J. Pharmacol. Exp. Ther. 282:208-219.

47. Alexander, C.M., et al. 2000. Syndecan-1 is required for Wnt-1-induced mammary tumorigenesis in mice. Nat. Genet. 25:329-332.

48. Stickens, D., et al. 2005. Mice deficient in Ext2 lack heparan sulfate and develop exostoses. Development.
132:5055-5068.

49. Inatani, M., et al. 2003. Mammalian brain morphogenesis and midline axon guidance require heparan sulfate. Science. 302:1044-1046.

50. Madison, B.B., et al. 2002. Cis elements of the villin gene control expression in restricted domains of the vertical (crypt) and horizontal (duodenum, cecum) axes of the intestine. J. Biol. Chem. 277:33275-33283. 51. Klein, N.J., Shennan, G.I., Heyderman, R.S., and Levin, M. 1993. Detection of glycosaminoglycans on the surface of human umbilical vein endothelial cells using gold-conjugated poly-L-lysine with sil- ver enhancement. Histochem. J. 25:291-298.

52. Bai, X., Wei, G., Sinha, A., and Esko, J.D. 1999. Chinese hamster ovary cell mutants defective in glycosaminoglycan assembly and glucuronosyltransferase I. J. Biol. Chem. 274:13017-13024.

53. Fuster, M.M., et al. 2007. Genetic alteration of endothelial heparan sulfate selectively inhibits tumor angiogenesis. J. Cell Biol. 177:539-549.

54. Ziomek, C.A., Schulman, S., and Edidin, M. 1980. Redistribution of membrane proteins in isolated mouse intestinal epithelial cells. J. Cell Biol. 86:849-857. 